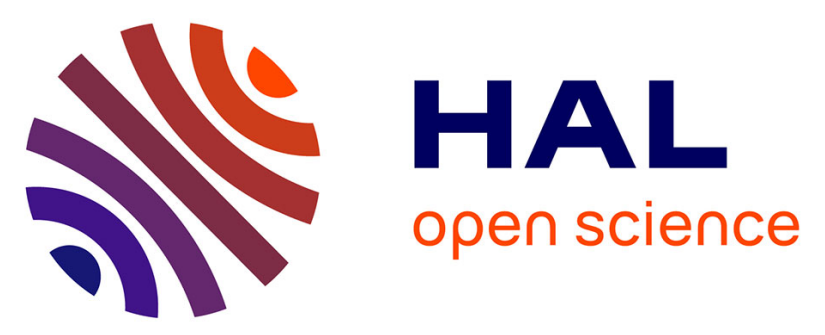

\title{
Tonantzitlolones from Stillingia lineata ssp. lineata as potential inhibitors of chikungunya virus
}

Sophie Techer, Emmanuelle Girard-Valenciennes, P. Retailleau, J. Neyts, F. Guéritte, P. Leyssen, M. Litaudon, Jacqueline Smadja, Isabelle Grondin

\section{- To cite this version:}

Sophie Techer, Emmanuelle Girard-Valenciennes, P. Retailleau, J. Neyts, F. Guéritte, et al.. Tonantzitlolones from Stillingia lineata ssp. lineata as potential inhibitors of chikungunya virus. Phytochemistry Letters, 2015, 12, pp.313-319. 10.1016/j.phytol.2015.04.023 . hal-01178980

\author{
HAL Id: hal-01178980 \\ https://hal.science/hal-01178980
}

Submitted on 16 Nov 2016

HAL is a multi-disciplinary open access archive for the deposit and dissemination of scientific research documents, whether they are published or not. The documents may come from teaching and research institutions in France or abroad, or from public or private research centers.
L'archive ouverte pluridisciplinaire HAL, est destinée au dépôt et à la diffusion de documents scientifiques de niveau recherche, publiés ou non, émanant des établissements d'enseignement et de recherche français ou étrangers, des laboratoires publics ou privés. 


\title{
Tonantzitlolones from Stillingia lineata ssp. lineata as potential inhibitors of chikungunya virus
}

\author{
S. Techer ${ }^{\text {a }}$, E. Girard-Valenciennes ${ }^{a}$, P. Retailleau ${ }^{c}$, J. Neyts ${ }^{b}$, F. Guéritte ${ }^{c}$, P. Leyssen ${ }^{b}$, M. Litaudon $^{c}$, \\ J. Smadja ${ }^{\text {a }}$, I. Grondin ${ }^{\text {a,* }}$ \\ a Laboratoire de Chimie des Substances Naturelles et des Sciences des Aliments (LCSNSA), Université \\ de La Réunion, 15, avenue René Cassin-CS 92003-97744 Saint-Denis Cedex 9, France \\ b Laboratory of Virology and Chemotherapy, Rega Institute for Medical Research, KU Leuven, \\ Minderbroedersstraat 10, B3000 Leuven, Belgium \\ ' Institut de Chimie des Substances Naturelles, CNRS-ICSN UPR2301, Université de Paris-Sud - 1, \\ Avenue de la Terrasse-91198 Gif-sur-Yvette, France
}

A B S T R A C T

With the purpose of discovering new chemical classes of molecules, in particular those with selective antiviral activity, extracts from plants growing in Reunion Island were systematically evaluated in a chikungunya virus-cell-based assay. The entire ethyl acetate extract obtained from the stem bark of Stillingialineatassp.lineata(Euphorbiaceae)exhibitedselectiveantiviralactivityagainstthe chikungunya virus with an EC50 $<0.8 \mu \mathrm{g} / \mathrm{mL}$, whereas only a weak cytotoxic effect was observed on the host cells. A phytochemical investigation of this extract led to the isolation of tonantzitlolone $A$ and tonantzitlolone B (1 and $\mathbf{2}$ ), together with the new $4^{\prime}$-hydroxytonantzitlolone, named tonantzitlolone C (3), which has an uncommon C15-flexibilane skeleton, as well as in the new ent-12 $\alpha$-hydroxy-3,7dioxoisopimara-8,15-diene (4). Subsequent evaluation for inhibition of chikungunya virus replication in cellulo demonstrated that the $4^{\prime}$-acetoxytonantzitlolone (2) was endowed with antiviral activity against CHIKV.

\section{Introduction}

Chikungunya is an arboviral disease that is typically characterized by myalgia, polyarthralgia, fever, nausea, headaches and maculopapular rash. The chikungunya virus (CHIKV) is an Aedes mosquitoes-transmitted alphavirus that belongs to the Togaviridae family (Kaur and Chu, 2013). Around a decade ago, there was a sudden reemergence of $\mathrm{CHIKV}$ infections with a previously unseen magnitude, with the virus moving from Africa throughout the Indian Ocean to India and Southeast Asia. Due to the steadily increasing number of cases, it became a serious concern and threat for public health (Thiberville et al., 2013). In 2005 and 2006, CHIKV caused a massive outbreak on Reunion Island, a French overseas territory, during which about 266,000 of the 775,000 inhabitants became infected (Renault et al., 2007). This was the dawn of a worldwide emergence of this virus, which has now even reached the Caribbean, the doorstep to the rest of the Americas. At present, no vaccine is yet available to prevent this infection, nor any antiviral drug(s) for treatment or prophylaxis.

\footnotetext{
* Corresponding author. Tel.: +262 262938191.

E-mail address: isabelle.grondin@univ-reunion.fr (I. Grondin).
}

The Reunion Island outbreak triggered our interest to explore the vast Indian Ocean plant biodiversity for novel natural molecules that selectively inhibit the replication of CHIKV. More than 1500 extracts from 972 endemic or indigenous plants from Madagascar, Mauritius and Reunion Island were evaluated for selective antiviral activity in a virus-cell-based assay for CHIKV (Leyssen et al., 2014).

Among them, the species Croton mauritianus (Euphorbiaceae) from Reunion Island was found to elicit biological activity and was selected for a phytochemical investigation, leading to the isolation of tigliane-type diterpenoids (Corlay et al., 2014). Tigliane-, daphnane- and jatrophane-type diterpenoids with potent and selective anti-CHIKV activities were also isolated from other Euphorbiaceae species: Trigonostemon cherrieri (Allard et al., 2012a,b; Bourjot et al., 2014), which is native to New Caledonia, T. howii (Bourjot et al., 2012), which is native to Vietnam, and the Corsican species Euphorbia amygdaloides ssp semiperfoliata (Nothias-Scaglia et al., 2014). These results prompted us to investigate another Euphorbiaceae species growing in Reunion Island, in casu Stillingia lineata ssp. lineata, of which the stem bark extract showed potent and selective anti-CHIK activity.

The genus Stillingia comprises 30 species that are mainly distributed in neotropical areas. In 1980, eight daphnane- and 
tigliane-type diterpenoids were isolated from roots of Stillingia sylvatica (Adolf and Hecker, 1980). Cembrene A, two novel diterpenes with rare flexibilane skeletons (tonantzitlolone $A$ and tonantzitlolone B), two new pimaranes, seven kauranes, three known atisanes, a new trachylobane, and the new pentacyclic diterpene sanguinolane with a novel skeleton have been reported from the roots of Stillingia sanguinolenta (Dräger et al., 2007).

Cytotoxic, proteolytic and antifungal activities have been reported for several species (Adolf and Hecker, 1980; Chapuis et al., 1988; Cota et al., 2011; Sequeiros et al., 2003). The in vitro cytotoxic activity of the species Stillingia lineata (Lam.) Müll. Arg. from Mauritius was evaluated on human tumor cells Co-115 (colon cancer), with petroleum ether and DCM leaf extracts that were highly cytotoxic (Chapuis et al., 1988). This species has two subspecies: the ssp. pacifica which is located in Malaysia, and the ssp. lineata, which is endemic to Mauritius and to Reunion Island. The latter is a medicinal plant that has been traditionally used in Mauritius for diabetes (Picot et al., 2014).

This study reports the bio-assay-guided fractionation of the EtOAc bark extract from $S$. lineata ssp. lineata in a virus-cell-based assay for CHIKV on Vero cells (green monkey kidney cells Cercopithecus aethiops), as well as the characterization of the purified diterpenes-the most predominant secondary metabolite in this plant species-by detailed analysis of their spectral data, using $500 \mathrm{MHz}$ 2D-NMR (COSY, NOESY, HSQC, HMBC) and mass spectrometry.

\section{Results and discussion}

A total of 320 EtOAc polyamide cartridge-filtered extracts were prepared from different parts of 171 Reunion Island plant species and were evaluated for selective antiviral activity in a CHIKV viruscell-based assay (Leyssen et al., 2014). The results of this screening indicated that the EtOAc extract that was obtained from eight species completely inhibited the virus from inducing cytopathic effects and without showing adverse effects on the host cell morphology and density compared to the untreated, uninfected cell control condition ( $\mathrm{EC}_{50}$ from $<0.8$ to $9.1 \mu \mathrm{g} / \mathrm{mL}$ ).

Among them, the $S$. lineata ssp. lineata EtOAc bark extract (Euphorbiaceae) was selected for its potent anti-CHIKV activity $\left(\mathrm{EC}_{50}<0,8 \mu \mathrm{g} / \mathrm{mL}\right)$ and weak cytotoxicity on Vero cells $\left(\mathrm{CC}_{50}=\right.$ $60.9 \mu \mathrm{g} / \mathrm{mL}$ ). This EtOAc extract was subjected to silica gel flash chromatography to give six fractions. The biologically active fractions F3, F4 and F5 $\left(E_{50}=7.23,2.01\right.$ and $2.05 \mu \mathrm{g} / \mathrm{mL}$, respectively) were further purified by preparative and semipreparative C18HPLC to yield three rare macrocycle C15-type diterpenes: tonantzitlolone $\mathrm{A}$, tonantzilolone $\mathrm{B}$ and $4^{\prime}$-hydroxytonantzitolone (compounds 1-3), and also ent-12 $\alpha$-hydroxy-3,7dioxoisopimara-8,15-diene (4), a new pimarane Fig. 1.

The total assignment of ${ }^{1} \mathrm{H}$ and ${ }^{13} \mathrm{C}$ NMR data of tonantzitlolones $\mathbf{1}, \mathbf{2}$ and $\mathbf{3}$ and compound $\mathbf{4}$ are presented in Tables 1 and 2 .

Compound 1 was isolated as a white powder. The HR-ESIMS indicated a $[\mathrm{M}+\mathrm{Na}]^{+}$ion peak at 487.2688 , which suggested a molecular formula of $\mathrm{C}_{26} \mathrm{H}_{40} \mathrm{O}_{7} \mathrm{Na}$ (calc. 487.2672), thus requiring seven double-bond equivalents. Compound $\mathbf{2}$ was obtained as an amorphous powder. The HR-ESIMS of the $[\mathrm{M}+\mathrm{Na}]^{+}$ion peak at $m / z$ 545.2717 suggested that the molecular formula of compound 2 as $\mathrm{C}_{28} \mathrm{H}_{42} \mathrm{O}_{9}$ (calculated for $\mathrm{C}_{28} \mathrm{H}_{42} \mathrm{O}_{9} \mathrm{Na}$ 545.2727), thus requiring eight double-bond equivalents. Considering the biological source, the ${ }^{1} \mathrm{H}$ and ${ }^{13} \mathrm{C}$ NMR spectroscopic data suggested that compounds $\mathbf{1}$ and $\mathbf{2}$ possessed the rare macrocycle C15-flexibilane skeleton and were identified through comparison with literature data as tonantzitlolone A and tonantzitlolone B (4'-acetoxytonantzitlolone) (Dräger et al., 2007; Wittenberg et al., 2004). Both compounds possess characteristic NMR features of these flexibilane-type diterpenoids, in particular a tertiary and a secondary hydroxy group (OH-9 and $\mathrm{OH}-10)$ and two tertiary methyl groups (C-19 and C-20). Amongst the four quaternary carbons of the macrocycle were found a keto group (C-4), a non-functionalized carbon (C-15)-already mentioned for the flexibilene (Kazlauskas et al., 1978)-two deshielded carbons (C-9 and C-11), an acetal, and an oxygen-bearing carbon. The same deshielding was observed for the tertiary carbons of these oxygenated bridges ( $C-5$ and C-14) as was found with other $\mathrm{CH}$ carbons. More particularly, the presence of the very deshielded C-9 flanked by two oxygen atoms was determined by chemical shift $\left(\delta C\right.$ 97) and by the ${ }^{2} \mathrm{~J}$ HMBC correlation from OH-9. The location of this acetal C-9 was confirmed by multiple HMBC correlations (for example, chemical shifts of compound 1) from $\mathrm{H}-8(\delta \mathrm{H} 4.89), \mathrm{H}-10(\delta \mathrm{H} 3.43), \mathrm{OH}-10$ $(\delta \mathrm{H} 3.10)$ and $\mathrm{H}-5(\delta \mathrm{H} 4.62)$, fixing the ether-ring position.

The X-ray diffraction analysis from crystals of compound 1 allowed us to confirm the absolute configuration of tonantzitlolone A that was previously established by Dräger and his colleagues as 3S,5R,7R,8R,9R,10S,11R,14S (Dräger et al., 2007). A perspective
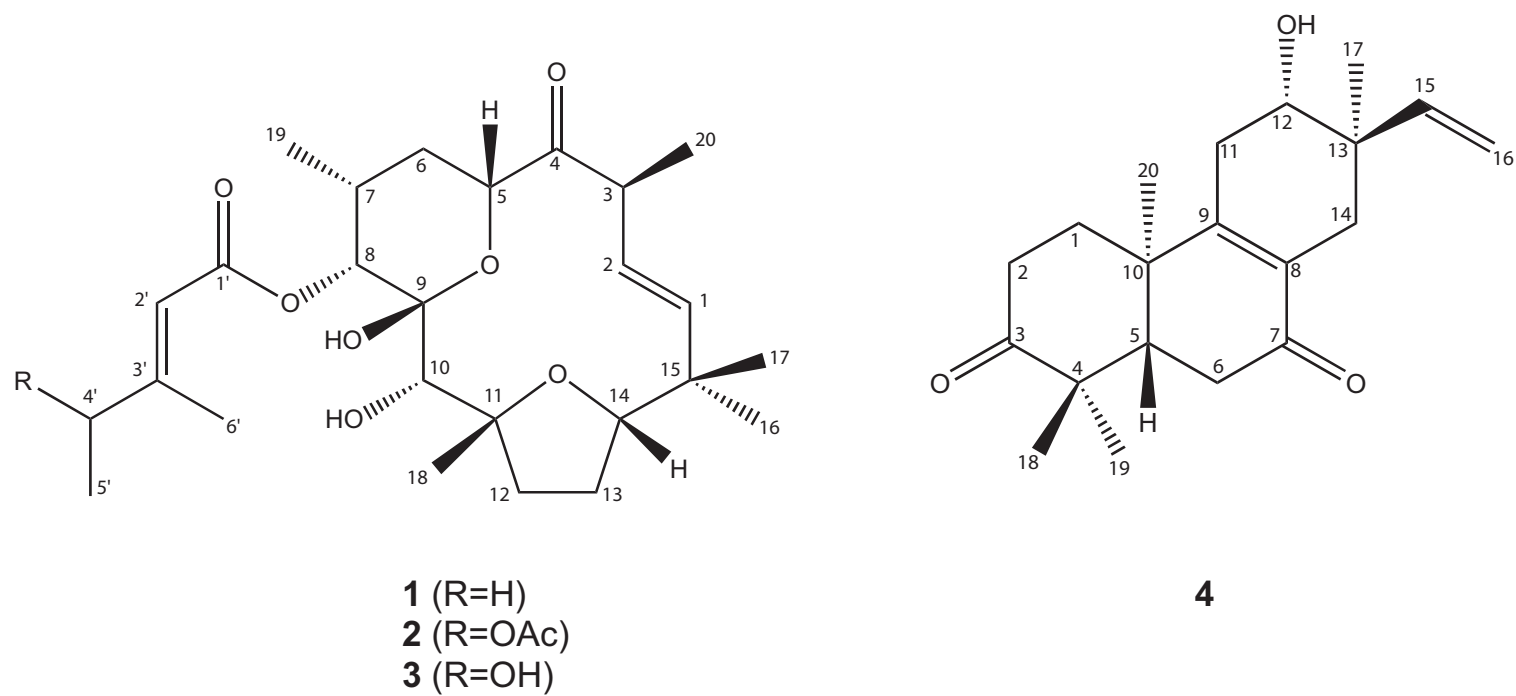

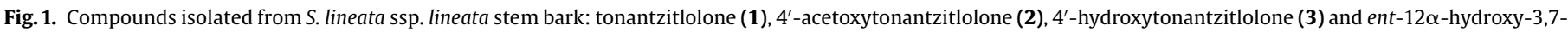
dioxoisopimara-8,15-diene (4). 
ORTEP plot is shown in Fig. 2. CCDC 1033736 contains the supplementary crystallographic data for this paper. These data can be obtained free of charge via www.ccdc.cam.ac.uk/conts/retrieving.html (or from the Cambridge Crystallographic Data Centre, 12 Union Road, Cambridge CB2 1EZ, UK; fax: +44 1223 336033; or deposit@ccdc.cam.uk).

The three-dimensional structure of 4'-acetoxytonantzitlolone (tonantzitlolone B) (2) does not differ from that of tonantzitlolone A. Its absolute configuration is, however, known through the work of Busch and his colleagues, in which the $R$ configuration was demonstrated (Busch et al., 2008).

Compound 3 possessed the molecular formula $\mathrm{C}_{26} \mathrm{H}_{40} \mathrm{O}_{8}$, based on its $\left[\mathrm{M}+\mathrm{Cl}^{-}\right.$ion peak at $\mathrm{m} / \mathrm{z} 515.2410$, obtained by HR-ESIMS (calculated for $\mathrm{C}_{26} \mathrm{H}_{40} \mathrm{O}_{8} \mathrm{Cl} 515.2412$ ), thus implying seven doublebond equivalents. In agreement with the mass spectrum, the ${ }^{13} \mathrm{C}$ NMR spectrum indicated the presence of 26 carbon atoms. The chemical shifts and the DEPT135 spectrum allowed us to highlight the presence of six quaternary carbons (one ketone carbonyl, one carbonyl ester, one olefinic, one oxygenated and two nonfunctionalized), three methylenes, seven methyls, and ten methines (three olefinic and five oxygenated). The ${ }^{1} \mathrm{H}$ and ${ }^{13} \mathrm{C}$ NMR spectra (Table 1) of compound $\mathbf{3}$ were very similar to those of the known compounds $\mathbf{1}$ and $\mathbf{2}$, thus one could deduce that the structure of compound $\mathbf{3}$ was a tonantzitlolone derivative. All the ${ }^{13} \mathrm{C}$ NMR signals of compound 3 were reminiscent to those of compound 2, except for carbons C $-2^{\prime}-\mathrm{C}-5^{\prime}(\delta \mathrm{C} 113.3,162.8,72.4$ and 21.5 , respectively for compound $\mathbf{3}$, and $115.2,157.6,73.8$ and 19.1, respectively for compound $\mathbf{2}$ ), suggesting the modification of the side chain. In the ${ }^{1} \mathrm{H}$ NMR and HSQC spectra, the presence of a deshielded quartet of doublets at $\delta \mathrm{H} 4.62(J=6.5,2.5 \mathrm{~Hz})$ attributable to proton $\mathrm{H}-4^{\prime}$, attached to $\mathrm{C}-4^{\prime}(\delta \mathrm{C} 72.4)$, suggested the presence of the $-\mathrm{CH}(\mathrm{OH})-\mathrm{CH}_{3}$ moiety. The HMBC correlation from this proton at $\delta \mathrm{H} 4.26$ to the olefinic and methyl carbons at $\delta \mathrm{C}$ $113.3\left(\mathrm{C}-2^{\prime}\right)$ and $15.3\left(\mathrm{C}-6^{\prime}\right)$ confirmed that the $-\mathrm{CH}(\mathrm{OH})-\mathrm{CH}_{3}$ moiety was located at $\mathrm{C}-3^{\prime}$. Consequently, the planar structure of compound $\mathbf{3}$ was elucidated as $4^{\prime}$-hydroxytonantzitlolone, named tonantzitlolone $\mathrm{C}$. The relative configuration of compound $\mathbf{3}$, with the exception of the stereocenter C- $4^{\prime}$, could be determined through the analysis of NOESY correlations, which are all comparable to those of compounds 1 and 2. In addition, since the specific rotation value of compound $3\left([\alpha]^{25}{ }_{D}+76[c 0.25\right.$, $\left.\mathrm{CHCl}_{3}\right]$ ) was found to have the same sign as the value found for tonantzitlonone $\mathrm{A}\left([\alpha]^{25}{ }_{\mathrm{D}}+134\left[\mathrm{c} 0.25, \mathrm{CHCl}_{3}\right]\right)$, it could be postulated that they possess the same absolute configuration (Dräger et al., 2007).

Compound 4 was obtained as an amorphous powder. The HRESIMS of the $[\mathrm{M}+\mathrm{H}]^{+}$ion peak at $m / z 317.2131$ allowed us to establish its molecular formula as $\mathrm{C}_{20} \mathrm{H}_{28} \mathrm{O}_{3}$ (calculated for $\mathrm{C}_{20} \mathrm{H}_{29} \mathrm{O}_{3}$ 317.2117), thus requiring seven double-bond equivalents. Its IR spectrum showed characteristic absorption bands at $3457 \mathrm{~cm}^{-1}$ for the hydroxy group, and 1707 and $1663 \mathrm{~cm}^{-1}$ for the carbonyl groups. The maximum absorption bands in the UV spectrum at $243 \mathrm{~nm}$ indicated the presence of an $\alpha, \beta$-unsaturated carbonyl. The occurrence in the ${ }^{1} \mathrm{H}$ NMR spectrum (Table 2) of a vinyl group with three dd resonances at $\delta \mathrm{H} 5.74(J=17.5$ and $10.8 \mathrm{~Hz}, \mathrm{H}-15), \delta \mathrm{H} 5.22$ ( $\mathrm{J}=10.8$ and $1.0 \mathrm{~Hz}, \mathrm{H}-16 \mathrm{cis}$ ), and $\delta \mathrm{H} 5.18$ $(J=17.5$ and $1.0 \mathrm{~Hz}, \mathrm{H}-16$ trans $)$ and the presence of four methyl group singlets suggested a pimarane-type skeleton. The analyses of ${ }^{1} \mathrm{H},{ }^{13} \mathrm{C}$, DEPT135, HMBC and HSQC NMR data revealed that compound 4 contains 20 carbons, including four singlet methyls,

Table 1

${ }^{1} \mathrm{H}$ and ${ }^{13} \mathrm{C}$ NMR spectroscopic data for tonantzitlolones (1-3) (in $\mathrm{CDCl}_{3}$, at 300 and $75 \mathrm{MHz}$, respectively; $\delta$ in ppm).

\begin{tabular}{|c|c|c|c|c|c|c|}
\hline \multirow[t]{2}{*}{ Position } & \multicolumn{2}{|l|}{1} & \multicolumn{2}{|l|}{2} & \multicolumn{2}{|l|}{3} \\
\hline & $\delta_{\mathrm{C}}$ & $\delta_{\mathrm{H}}$, mult, $\mathrm{J}(\mathrm{Hz})$ & $\delta_{\mathrm{C}}$ & $\delta_{\mathrm{H}}$, mult, $\mathrm{J}(\mathrm{Hz})$ & $\delta_{\mathrm{C}}$ & $\delta_{\mathrm{H}}$, mult, $\mathrm{J}(\mathrm{Hz})$ \\
\hline 1 & 140,1 & $5,85(\mathrm{~d}, 1 \mathrm{H}, 15.5)$ & 140,1 & $5,85(\mathrm{~d}, 1 \mathrm{H}, 15.0)$ & 140,0 & $5,85(\mathrm{~d}, 1 \mathrm{H}, 15.5)$ \\
\hline 2 & 126,8 & $5,23(\mathrm{dd}, 1 \mathrm{H}, 15.5,9.5)$ & 126,8 & $5,24(\mathrm{dd}, 1 \mathrm{H}, 15.5,9.5)$ & 126,8 & $5,23(\mathrm{dd}, 1 \mathrm{H}, 15.5,9.5)$ \\
\hline 3 & 49,5 & $3,33(\mathrm{dq}, 1 \mathrm{H}, 9.5,7.0)$ & 49,5 & $3,32(\mathrm{dq}, 1 \mathrm{H}, 9.5,7.0)$ & 49,5 & $3,34(\mathrm{dq}, 1 \mathrm{H}, 9.5,7.0)$ \\
\hline 4 & 211,3 & - & 211,2 & - & 211,2 & - \\
\hline 5 & 74,1 & $4,62(\mathrm{dd}, 1 \mathrm{H}, 12.0,3.0)$ & 74,1 & $4,62(\mathrm{dd}, 1 \mathrm{H}, 12.0,3.0)$ & 74,1 & $4,62(\mathrm{dd}, 1 \mathrm{H}, 12.0,3.0)$ \\
\hline $6 \alpha$ & 28,8 & $1,84(\mathrm{dt}, 1 \mathrm{H}, 13.5,3.5)$ & 28,7 & $1,84(\mathrm{dt}, 1 \mathrm{H}, 13.5,3.5)$ & 28,8 & $1,85(\mathrm{ddd}, 1 \mathrm{H}, 13.0,3.0,2.5)$ \\
\hline $6 \beta$ & & $1,40(\mathrm{ddd}, 1 \mathrm{H}, 13.5,12.5,3.0)$ & & $1,40(\mathrm{ddd}, 1 \mathrm{H}, 13.5,12.5,3.0)$ & & $1,39(\mathrm{ddd}, 1 \mathrm{H}, 13.5,12.5,3.0)$ \\
\hline 7 & 29,0 & $2,33$ (dddq, $1 \mathrm{H}, 12.5,7.0,4.0,2.5)$ & 29,0 & $2,32$ (dddq, $1 \mathrm{H}, 12.5,7.0,4.0,2.5)$ & 29,0 & 2,33 (dddq, $1 \mathrm{H}, 11.5,7.0,4.0,2.5$ ) \\
\hline 8 & 73,2 & $4,89(\mathrm{~d}, 1 \mathrm{H}, 2.5)$ & 73,7 & $4,90(\mathrm{~d}, 1 \mathrm{H}, 2.5)$ & 73,5 & $4,90(\mathrm{~d}, 1 \mathrm{H}, 2.5)$ \\
\hline 9 & 97,1 & - & 97,1 & - & 97,0 & - \\
\hline 10 & 78,2 & $3,43(\mathrm{~d}, 1 \mathrm{H}, 6.0)$ & 78,1 & 3,40 (br.d, $1 \mathrm{H}, 6.0$ ) & 78,2 & 3,41 (br.d, $1 \mathrm{H}, 2.5$ ) \\
\hline 11 & 87,6 & - & 87,7 & & 87,6 & - \\
\hline $12 \alpha$ & 37,3 & $1,53$ (ddd, $1 \mathrm{H}, 12.5,12.5,7.5)$ & 37,3 & $1,53$ (ddd, $3 \mathrm{H}, 12.5,12.5,7.5)$ & 37,3 & $1,53(\mathrm{ddd}, 1 \mathrm{H}, 12.5,12.5,7.5)$ \\
\hline $12 \beta$ & & $2,44(\mathrm{dd}, 1 \mathrm{H}, 12.5,7.5)$ & & $2,43(\mathrm{dd}, 1 \mathrm{H}, 12.5,7.5)$ & & $2,41(\mathrm{dd}, 1 \mathrm{H}, 12.5,7.5)$ \\
\hline $13 \alpha$ & 28,0 & $1,76(\mathrm{ddd}, 1 \mathrm{H}, 12.5,7.5,5.0)$ & 28,0 & $1,76(\mathrm{ddd}, 1 \mathrm{H}, 12.5,7.5,5.0)$ & 28,0 & $1,76(\mathrm{ddd}, 1 \mathrm{H}, 12.5,7.5,5.0)$ \\
\hline $13 \beta$ & & $2,04($ dddd, $1 \mathrm{H}, 12.5,12.5,12.5,7.5)$ & & $2,03$ (dddd, $1 \mathrm{H}, 13.0,13.0,11.5,7.5)$ & & $2,03($ dddd, $1 \mathrm{H}, 11.5,11.5,11.5,7.5)$ \\
\hline 14 & 88,9 & $3,76(\mathrm{dd}, 1 \mathrm{H}, 11.5,5.0)$ & 88,9 & $3,76(\mathrm{dd}, 1 \mathrm{H}, 11.5,5.0)$ & 88,9 & $3,76(\mathrm{dd}, 1 \mathrm{H}, 11.5,5.0)$ \\
\hline 15 & 38,7 & - & 38,7 & - & 38,7 & - \\
\hline 16 & 25,4 & $0,91(\mathrm{~s}, 3 \mathrm{H})$ & 25,4 & $0,91(\mathrm{~s}, 3 \mathrm{H})$ & 25,4 & $0,91(\mathrm{~s}, 3 \mathrm{H})$ \\
\hline 17 & 25,1 & $1,14(\mathrm{~s}, 3 \mathrm{H})$ & 25,1 & $1,13(\mathrm{~s}, 3 \mathrm{H})$ & 25,1 & $1,14(\mathrm{~s}, 3 \mathrm{H})$ \\
\hline 18 & 28,1 & $1,37(\mathrm{~s}, 3 \mathrm{H})$ & 28,1 & $1,37(\mathrm{~s}, 3 \mathrm{H})$ & 28,1 & $1,37(\mathrm{~s}, 3 \mathrm{H})$ \\
\hline 19 & 17,0 & $0,84(\mathrm{~d}, 3 \mathrm{H}, 7.0)$ & 17,0 & $0,84(\mathrm{~d}, 3 \mathrm{H}, 7.0)$ & 17,0 & $0,85(\mathrm{~d}, 3 \mathrm{H}, 7.0)$ \\
\hline 20 & 16,0 & $1,11(\mathrm{~d}, 3 \mathrm{H}, 7.0)$ & 16,0 & $1,12(\mathrm{~d}, 3 \mathrm{H}, 7.0)$ & 16,0 & $1,12(\mathrm{~d}, 3 \mathrm{H}, 7.0)$ \\
\hline $1^{\prime}$ & 166,6 & - & 166,3 & - & 166,5 & - \\
\hline $2^{\prime}$ & 113,9 & $5,69(\mathrm{q}, 1 \mathrm{H}, 1.5)$ & 115,2 & $5,90(\mathrm{q}, 1 \mathrm{H}, 1.2)$ & 113,3 & $6,00(\mathrm{~s}, 1 \mathrm{H})$ \\
\hline $3^{\prime}$ & 163,0 & - & 157,6 & & 162,8 & - \\
\hline $4^{\prime}$ & 33,9 & $2,17(q, 2 H, 7.0)$ & 73,8 & $5,27(\mathrm{q}, 1 \mathrm{H}, 6.5)$ & 72,4 & $4,62(\mathrm{dq}, 1 \mathrm{H}, 6.5,2.5)$ \\
\hline $5^{\prime}$ & 11,8 & $1,07(t, 3 \mathrm{H}, 7.5)$ & 19,1 & $1,35(\mathrm{~d}, 3 \mathrm{H}, 7.0)$ & 21,5 & $1,32(\mathrm{~d}, 1 \mathrm{H}, 6.5)$ \\
\hline $6^{\prime}$ & 19,0 & $2,15(\mathrm{~d}, 3 \mathrm{H}, 1.5)$ & 15,2 & $2,13(\mathrm{~d}, 3 \mathrm{H}, 1.5)$ & 15,3 & $2,12(\mathrm{~s}, 1 \mathrm{H})$ \\
\hline $1^{\prime \prime}$ & & & 170,1 & - & & \\
\hline $2^{\prime \prime}$ & & & 21,2 & $2,09(\mathrm{~s}, 3 \mathrm{H})$ & & \\
\hline $\mathrm{OH}-4^{\prime}$ & & & & & & Not resolved \\
\hline OH-9 & & $5,65(\mathrm{~s}, 1 \mathrm{H})$ & & $5,70(\mathrm{~s}, 1 \mathrm{H})$ & & $5,63(\mathrm{~s}, 1 \mathrm{H})$ \\
\hline $\mathrm{OH}-10$ & & $3,10(\mathrm{~d}, 1 \mathrm{H}, 6.0)$ & & 3,05 (br.d, $1 \mathrm{H}, 6.5$ ) & & $3,15(\mathrm{~d}, 1 \mathrm{H}, 5.5)$ \\
\hline
\end{tabular}


Table 2

${ }^{1} \mathrm{H}$ and ${ }^{13} \mathrm{C}$ NMR spectroscopic data for ent-12 $\alpha$-hydroxy-3,7-dioxoisopimara-8,15-diene (4) (in $\mathrm{CDCl}_{3}$, at 500 and $75 \mathrm{MHz}$, respectively).

\begin{tabular}{|c|c|c|c|}
\hline Position & $\delta_{\mathrm{C}}$ & $\delta_{\mathrm{H}}$, mult., (J en $\mathrm{Hz}$ ) & NOESYa $^{\mathrm{a}}$ \\
\hline $1 \alpha$ & 34,5 & $2,17$ (ddd, $1 \mathrm{H}, 13.0,6.0,3.0)$ & $2 \alpha, 20$ \\
\hline $1 \beta$ & & $1,78(\mathrm{td}, 1 \mathrm{H}, 13.0,6.0)$ & $2 \beta, 5$ \\
\hline $2 \alpha$ & 34,6 & $2,74$ (ddd, $1 \mathrm{H}, 16.0,13.0,6.0)$ & $1 \alpha, 19,20$ \\
\hline $2 \beta$ & & $2,48(\mathrm{ddd}, 1 \mathrm{H}, 16.0,6.0,3.0)$ & $1 \beta$ \\
\hline 3 & 218,8 & - & - \\
\hline 4 & 46,5 & - & - \\
\hline 5 & 49,8 & $2,20(\mathrm{dd}, 1 \mathrm{H}, 14.0,4.0)$ & $1 \beta 11 \beta, 18$ \\
\hline $6 \alpha$ & 35,4 & $2,53(\mathrm{dd}, 1 \mathrm{H}, 17.5,14.0)$ & 19,20 \\
\hline $6 \beta$ & & $2,46(\mathrm{dd}, 1 \mathrm{H}, 17.5,4.0)$ & 18 \\
\hline 7 & 204,8 & - & - \\
\hline 8 & 133,0 & - & - \\
\hline 9 & 160,8 & - & - \\
\hline 10 & 38,8 & - & - \\
\hline $11 \alpha$ & 30,3 & $2,22(\mathrm{dd}, 1 \mathrm{H}, 17.5,9.0)$ & 17 \\
\hline $11 \beta$ & & $2,58(\mathrm{dd}, 1 \mathrm{H}, 17.5,5.5)$ & $5,12 \beta, 14 \beta$ \\
\hline $12 \beta$ & 71,0 & $3,61(\mathrm{dd}, 1 \mathrm{H}, 9.0,5.5)$ & $11 \beta, 14 \beta, 15$ \\
\hline 13 & 40,0 & - & - \\
\hline $14 \alpha$ & 34,2 & $2,35(\mathrm{~d}, 1 \mathrm{H}, 17.0)$ & 17 \\
\hline $14 \beta$ & & $2,23(\mathrm{~d}, 1 \mathrm{H}, 17.0)$ & $11 \beta, 12 \beta, 15$ \\
\hline 15 & 144,7 & $5,74(\mathrm{dd}, 1 \mathrm{H}, 17.5,10.8)$ & $12 \beta, 14 \beta$ \\
\hline 16 cis & 115,5 & $5,22(\mathrm{dd}, 1 \mathrm{H}, 10.8,1.0)$ & - \\
\hline 16trans & & $5,18(\mathrm{dd}, 1 \mathrm{H}, 17.5,1.0)$ & 17 \\
\hline 17 & 15,0 & $0,93(\mathrm{~s}, 3 \mathrm{H})$ & $11 \alpha, 14 \alpha, 16$ trans \\
\hline 18 & 25,2 & $1,11(\mathrm{~s}, 3 \mathrm{H})$ & $5,6 \beta$ \\
\hline 19 & 21,4 & $1,14(\mathrm{~s}, 3 \mathrm{H})$ & $2 \alpha, 6 \alpha, 20$ \\
\hline 20 & 17,3 & $1,30(\mathrm{~s}, 3 \mathrm{H})$ & $1 \alpha, 2 \alpha, 6 \alpha, 19$ \\
\hline $\mathrm{OH}$ & & 2,24 (br.s, $1 \mathrm{H}$ ) & - \\
\hline
\end{tabular}

a Key NOESY cross peaks.

six methylenes (one $\mathrm{sp}^{2}$ and five $\mathrm{sp}^{3}$ ), three methine (one $\mathrm{sp}^{2}$ and two $\mathrm{sp}^{3}$ ), seven quaternary carbons (one $\alpha, \beta$-unsaturated carbon$\mathrm{yl}$, and one oxygenated $\mathrm{sp}^{2}$, two $\mathrm{sp}^{2}$ and three $\mathrm{sp}^{3}$ ). The key 2D NMR correlations of compound $\mathbf{4}$ are presented in Fig. 3. The relative configuration of compound 4 was deduced from ${ }^{1} \mathrm{H}-{ }^{1} \mathrm{H}$ vicinal coupling constants and NOESY correlations. Cross peaks observed between Me-20 and Me-19, $\mathrm{H}-1 \alpha, \mathrm{H}-2 \alpha$ and $\mathrm{H}-6 \alpha$ suggested that they are cofacial and, thus indicated that Me-20 is $\alpha$-oriented as observed for an ent structure. The relative configuration of C-5 was established by the correlations between $\mathrm{H}-5$ and $\mathrm{Me}-18$ on the one hand, and between $\mathrm{H}-5$ and $\mathrm{H}-1 \beta$, on the other hand, which is consistent with a $\beta$-orientation. This stereochemistry was also supported by the axial-axial coupling constants shown by both $\mathrm{H}-5$ and $\mathrm{H}-6 \alpha$ (Table 2). The hydroxymethine proton $\mathrm{H}-12$ resonated as a dd at $\delta \mathrm{H} 3.61$ with coupling constants of 9.0 and $5.5 \mathrm{~Hz}$. The magnitude of these coupling constants suggests the axial position for this proton. Moreover both $\mathrm{H}-12$ and $\mathrm{H} 14 \beta$ are cross-correlated and both are also correlated with H-15 and H-11ß.

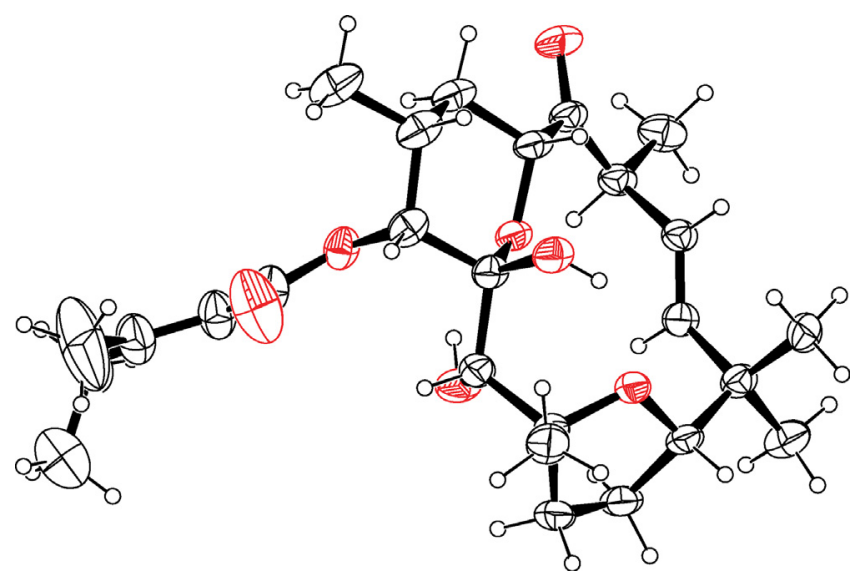

Fig. 2. An ORTEP-3 view of the tonantzitlolone A (1). Ellipsoids are drawn at the $30 \%$ probability level.
Thus, the anti-position of $\mathrm{H}-15$ compared to Me-20 suggests an isopimarane structure. In addition, the negative value of the optical rotation $\left(-225, \mathrm{CHCl}_{3}, c=0.20 \mathrm{mg} / \mathrm{mL}\right)$ of compound 4 is the same sign as those measured for other ent-pimarane derivatives (Luo et al., 2001; Rayanil et al., 2013). Compound 4 was, therefore, elucidated as ent-12 $\alpha$-hydroxy-3,7-dioxoisopimara-8,15-diene.

It should be emphasized that the macrocycle-15C diterpene skeleton of compounds $\mathbf{1}, \mathbf{2}$ and $\mathbf{3}$ is particularly unusual in natural products. To the best of our knowledge, this constitutes the third example of tonantzitlolone-type diterpenes isolated from higher plants. The tonantzitlolone A (1) was isolated for the first time by Dräger et al. (2007) from Stillingia sanguinolenta, an endemic species of Mexico, and later on from Sebastiania macrocarpa (Euphorbiaceae) (Lima et al., 2009). These compounds-including tonantzitlolone B (2), which was also isolated from Stillingia sanguinolenta (Dräger et al., 2007)-have not yet been identified in other plants. The tonantzitlolone $\mathrm{C}$ (4'-hydroxytonantzitlolone (3)) represents the third natural compound of this chemical series that possesses a 15C-macrocycle flexibilen carbon skeleton. This original skeleton is also found in the structure of flexibilen, which was isolated from the soft coral Sinularia flexibilis (Hérin et al., 1976; McMurry et al., 1982). Unlike tonantzitlolones, the pimaranes have been isolated from different genera and families. Two pimaranes were previously isolated from $S$. sanguinolenta: the ent-8$\beta$-hydroxy3,12-dioxopimara-9(11), 15-diene and the ent-3 $\beta, 12 \alpha-8$-dihydroxypimara,15-diene, which belong to the enantiomeric series (Dräger et al., 2007).

The antiviral properties of the isolated compounds were evaluated in a CHIKV virus-cell-based assay, with chloroquine as a reference compound. Only the $4^{\prime}$-acetoxytonantzitlolone (2) selectively inhibited virus-induced cell death, with $\mathrm{EC}_{50}$ and SI (selectivity index, calculated as $\mathrm{CC}_{50}$ Vero/EC $\mathrm{E}_{50} \mathrm{CHIKV}$ ) values of $7 \mu \mathrm{M}$ and 8.8, respectively, while $4^{\prime}$-hydroxytonantzitlolone (3) was not significantly selective $\left(\mathrm{EC}_{50}: 34 \mu \mathrm{M}\right.$; SI:3.2). A comparison of the structures of these two bioactive compounds reveals that the presence of an acetyl group is possibly an important element in improving the inhibitory activity. 

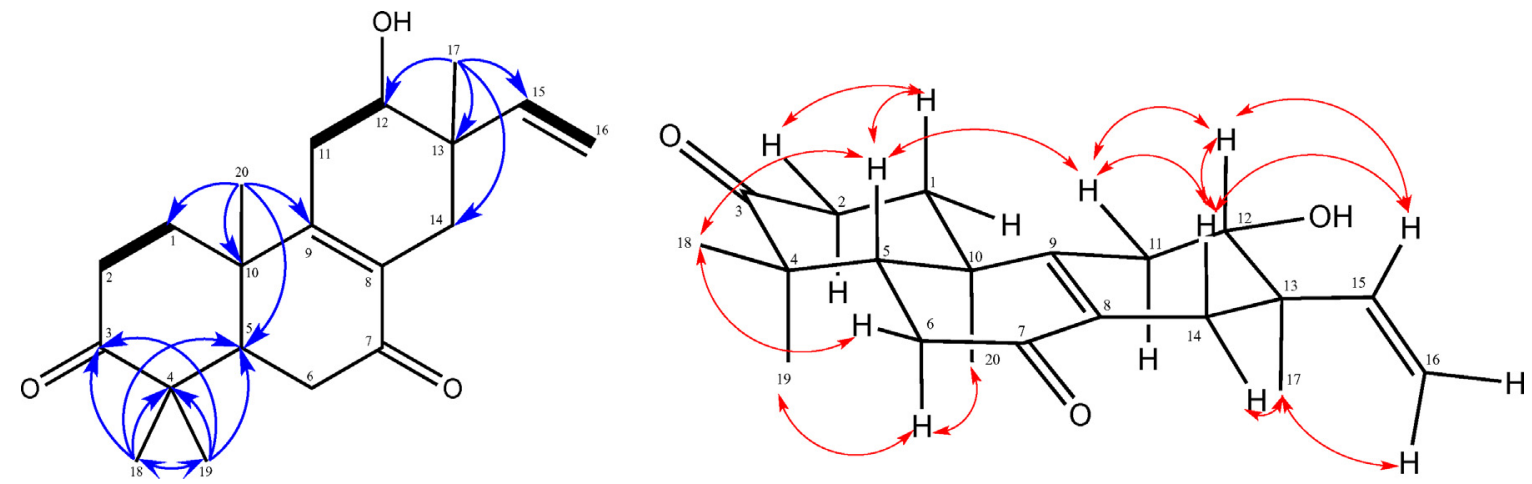

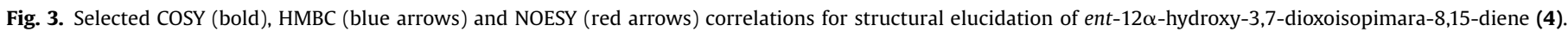
(For interpretation of the references to color in this figure legend, the reader is referred to the web version of this article.)

In conclusion, the bioguided fractionation of the bark of Stillingia lineata ssp. lineata resulted in the isolation and characterisation of two new diterpenes (3 and 4), together with two known molecules ( $\mathbf{1}$ and $\mathbf{2}$ ). Their structures were elucidated mainly by 2D-NMR techniques and mass spectrometry. The isolated molecules were only slightly active against CHIKV in their purified state. The more pronounced antiviral activity of the extract could be due to additive or synergistic effects by other compounds that are present in low amounts. The correlation between the structure and biological activity of these tonantzitlolones is not yet complete. Therefore, further investigation of these active diterpenes in the context of CHIKV is required not only to elucidate the structure-activity relationship but also to enable the study of the molecular mechanism of action.

\section{Experimental}

\subsection{General}

Optical rotations were measured using a Jasco P1010 or an Anton Paar MCP200 polarimeter. UV spectra were acquired on a Varian Cary 100 Scan spectrophotometer. IR spectra were recorded on a PerkinElmer Spectrum FT-IR 100 spectrophotometer. NMR spectra were recorded on a Bruker Avance $300 \mathrm{MHz}$ or $500 \mathrm{MHz}$ instrument at $25^{\circ} \mathrm{C} .{ }^{1} \mathrm{H}$ - and ${ }^{13} \mathrm{C}$ NMR chemical shifts refer to $\mathrm{CHCl}_{3}$ at $7.26 \mathrm{ppm}$, and to $\mathrm{CDCl}_{3}$ at $77.0 \mathrm{ppm}$, respectively. Coupling constants are in Hz. HR-ESIMS data were obtained on a Thermoquest TLM LCQ Deca ion-trap spectrometer. X-ray crystallographic data were collected using a Rigaku diffractometer constituted by a MM007HF rotating-anode generator, equipped with Osmic confocal optics, delivering filtered $\mathrm{Cu}-\mathrm{K} \alpha$ radiation $(\lambda=1.54187 \AA)$ and a Rapid II curved Image Plate, at a cryogenic temperature (193 K).

Flash chromatographies were performed on a Sepacore system (Büchi) or a CombiFlash Companion apparatus (Teledyne Isco), using silica gel $60 \mathrm{~A}$ or various prepacked normal-phase cartridges (Silicycle ${ }^{\circledR}$ 15-40 $\mu \mathrm{m}$, Redisep ${ }^{\circledR}$ 15-60 $\mu \mathrm{m}$, Redisep ${ }^{\circledR}$ $35-70 \mu \mathrm{m}$, or $\left.\operatorname{Versapack}^{\circledR} 45-75 \mu \mathrm{m}\right)$. All solvents were purchased from Carlo Erba (France). TLC separations were performed on Merck precoated silica gel 60G F254, Alugram ${ }^{\circledR}$ SIL G/UV254 (Macherey-Nagel) or Alugram ${ }^{\circledR}$ RP-18W/UV254 (Macherey-Nagel) analytical plates. Kromasil reversed-phase semi-preparative and preparative HPLC separations were carried out on Thermo Hypersil columns $(250 \times 10 \mathrm{~mm}$ and $250 \times 21 \mathrm{~mm}$ ID, $5 \mu \mathrm{m}$ ), using Waters ${ }^{\circledR}$ apparatus (Alliance 2695 and Autopurification system Waters ${ }^{\mathbb{R}}-2767$ Sample Manager) equipped with a binary pump (Waters 2525), a UV-vis diode array detector $\left(190-600 \mathrm{~nm}\right.$, Waters ${ }^{\circledR}$ 2996), and a PL-ELS 1000 ELSD detector (Polymer Laboratory).

\subsection{Plant material}

The whole plant of Stillingia lineata ssp. lineata was collected in March 2011 in Langevin (La Réunion, France) and was authenticated by the botanist Prof. Dominique Strasberg (University of La Réunion). A voucher specimen (No. REU09532) was deposited in the Herbarium of the University of La Réunion, France.

\subsection{Extraction and isolation}

Seven hundred sixty-nine grams of dried powder of bark of Stillingia lineata ssp. lineata were extracted with EtOAc, using a Dionex-accelerated solvent extractor equipped with $100 \mathrm{~mL}$ of stainless steel cells and $250 \mathrm{~mL}$ of collection bottles (ASE300, Voisins Le Bretonneux, France). Conditions were as follows: temperature, $40^{\circ} \mathrm{C}$; pressure, 100 bars; 5 cycles with static extraction time of $6 \mathrm{~min}$; and flush volume, 100\%. The EtOAc crude extract was concentrated under reduced pressure to yield $33.9 \mathrm{~g}$ of residue $(\rho=4.4 \% \mathrm{w} / \mathrm{w})$. This EtOAc extract was subjected to flash silica chromatography using a gradient of cyclohexane-AcOEt $(95: 5-0: 100)$ and AcOEt-MeOH (100:0-50:50) at $15 \mathrm{~mL} / \mathrm{min}$ to produce six fractions, according to their TLC profiles. The biologically active fractions $\mathrm{F} 3\left(8.3 \mathrm{~g}, \mathrm{EC}_{50}=7.23 \mu \mathrm{g} / \mathrm{mL}\right), \mathrm{F} 4(4.7 \mathrm{~g}$, $\left.\mathrm{EC}_{50}=2.91 \mu \mathrm{g} / \mathrm{mL}\right)$, and F5 $\left(3.5 \mathrm{~g}, \mathrm{EC}_{50}=2.05 \mu \mathrm{g} / \mathrm{mL}\right)$ were further purified using successive preparative and semi-preparative chromatographies on reversed-phase silica gel in the C-18 column. Purifications of fraction F3 (8.3 g, cyclohexane-AcOEt 80:20) were carried out by preparative RP-18HPLC chromatography (Thermohypersil Kromasil, $5 \mu \mathrm{m}, 250 \times 21.2 \mathrm{~mm}$ ) to produce tonantzitlolone A (1), using $\mathrm{MeOH}-\mathrm{H}_{2} \mathrm{O}+0.1 \%$ formic acid (from $80: 20$ to $100: 0$ in $20 \mathrm{~min}$ at $\left.21 \mathrm{~mL} / \mathrm{min} ; t_{\mathrm{R}} 18.9 \mathrm{~min}\right)$. Fraction $\mathrm{F} 4(4.7 \mathrm{~g}$, cyclohexane-AcOEt $80: 20$ ) was separated by preparative HPLC (Kromasil RP-18 using $\mathrm{MeOH}-\mathrm{H}_{2} \mathrm{O}+0.1 \%$ formic acid, from 70:30 to $100: 0$ in $30 \mathrm{~min}$ at $15 \mathrm{~mL} / \mathrm{min}$ ) to give the $4^{\prime}$-acetoxytonantzitlolone (2) $\left(19.7 \mathrm{mg}, t_{\mathrm{R}} 20.3 \mathrm{~min}\right.$ ). The fraction F5 (3.5 g, eluting from 70:30 to $50: 50$ cyclohexane-AcOEt) was subjected to preparative RP18HPLC to yield compound $3\left(9.3 \mathrm{mg}, t_{\mathrm{R}} 17.2 \mathrm{~min}\right)$ and a sub-fraction $5-5$ (20 mg). This sub-fraction 5-5 was further purified by a semipreparative HPLC (Thermo Hypersil Kromasil, $\mathrm{MeOH}-\mathrm{H}_{2} \mathrm{O}+0.1 \%$ formic acid, from $60: 40$ to $100: 0$ in $50 \mathrm{~min}$ at $4.7 \mathrm{~mL} / \mathrm{min}$ ) to get compound $\mathbf{4}$ (1.2 mg).

4'-Hydroxytonantzitlolone (tonantzitlolone C) (3)

White, amorphous powder; $[\alpha]^{23}{ }_{\mathrm{D}}+76^{\circ}$ (c $0.25, \mathrm{CHCl}_{3}$ ); UV $\left(\mathrm{CHCl}_{3}\right) \lambda_{\max }(\log \varepsilon) 240(2.46) \mathrm{nm} ; \mathrm{IR} v_{\max }\left(\mathrm{cm}^{-1}\right): 3372,2967$, 2933, 1712; ${ }^{1} \mathrm{H}$ and ${ }^{13} \mathrm{C}$ NMR $\left(\mathrm{CHCl}_{3}\right)$ data, see Table 1 ; HR-ESIMS (neg.) $\mathrm{m} / z 515.2410$ (calculated for $\mathrm{C}_{26} \mathrm{H}_{40} \mathrm{O}_{8} \mathrm{Cl}, 515.2412$ ).

Ent-12 $\alpha$-hydroxy-3,7-dioxoisopimara-8,15-diene (4)

White, amorphous powder; $[\alpha]^{23}{ }_{\mathrm{D}}-225^{\circ}$ ( c $0.20, \mathrm{CHCl}_{3}$ ); UV $\left(\mathrm{CHCl}_{3}\right) \lambda_{\max }(\log \varepsilon) 201$ (1.83) 227 (2.01) 243 (2.36) nm; IR $v_{\max }$ 
$\left(\mathrm{cm}^{-1}\right): 3457,2924,1707,1663,1380 ;{ }^{1} \mathrm{H}$ and ${ }^{13} \mathrm{C} \mathrm{NMR}\left(\mathrm{CHCl}_{3}\right)$ data, see Table 2; HR-ESIMS (pos.) $m / z 317.2131$ (calcd. for $\mathrm{C}_{20} \mathrm{H}_{29} \mathrm{O}_{3}$, 317.2117).

\subsection{X-ray crystallographic analysis of 1}

A large colourless crystal of tonantzitlolone A (1), recrystallized from isopropyl oxide, was mounted at cryogenic temperature ( $193 \mathrm{~K}$ ) on a Rigaku diffractometer constituted by a MM007HF rotating-anode generator, equipped with Osmic confocal optics, delivering filtered $\mathrm{Cu}-\mathrm{K} \alpha$ radiation $(\lambda=1.54187 \AA)$ and a Rapid II curved Image Plate. The crystal-to-detector distance was $127.40 \mathrm{~mm}$. The X-ray data were collected up to a maximum $2 \theta$ value of $136.5^{\circ}$. Four images with one degree $\omega$ oscillation spanning a $60^{\circ} \omega$ angular space were used to derive cell constants and matrix orientation using $d^{*}$ trek (Pflugrath, 1999). According to a subsequent strategy in mmm symmetry, a total of 108 oscillation images were collected from three sweeps of data using $\omega$ oscillations in $5.0^{\circ}$ steps. The exposure rate was $60.0 \mathrm{~s}$ per degree. Data reduction and scaling were carried out using Fs_Process. ${ }^{2}$. The structure was solved by Direct methods (SHELXS-97) and by subsequent difference Fourier syntheses, and refined by full matrix least squares on $F^{2}$ using the SHELXL-2014/6 (Sheldrick, 2008). Anisotropic thermal parameters were used for all non-hydrogen atoms whereas hydrogen atoms, located from difference Fourier maps, were refined as a riding model with $U_{\text {iso }}=1.2 U_{\text {eq }}$ of the parent atom ( 1.5 for the methyl hydrogen atoms and the hydroxyl hydrogen ones). The C28 methyl carbon atom went to nonpositive-definite and was further restrained with a soft ISOR (esd 0.04 ) restraint to be approximately isotropic. Despite the absence of strong anomalous scatterers (Friedif value of 34 (Flack and Shmueli, 2007)), the absolute configuration was attributed with some confidence by the use of the Hooft y parameter (Hooft et al., 2008), calculated as 0.03 (5), the P2(true) and P3(true) values being both 1.000 , from a total of 1979 Bijvoet pairs (97\% coverage). This Bayesian analysis on the Bijvoet pairs implemented in Platon (Spek, 2009) enhanced the weak significance of the Flack $x$ parameter (Flack, 1983), which was determined to be $x=0.1$ (3) by the use of 1519 quotients $[(\mathrm{I}+)-(\mathrm{I}-)] /[(\mathrm{I}+)+(\mathrm{I}-)]$ from the Parsons' method (Parsons et al., 2013)

The crystallographic data are summarized as follows: a colourless tab with dimensions $0.60 \times 0.48 \times 0.12 \mathrm{~mm}, \mathrm{C}_{26} \mathrm{H}_{40}$ $\mathrm{O}_{7}, \mathrm{Mr}=464.58$, an orthorhombic system, space group $P 22_{1} 2_{1} 2_{1}$, $Z=2, a=10.1348(2) \AA, b=10.2248(2) \AA, c=25.1440(18) \AA, V=2605.6$ (2) $\AA^{3}, D_{\text {calcd. }}=1.184 \mathrm{~g} / \mathrm{cm}^{3}, F(000)=1,008, \mu=0.690 \mathrm{~mm}^{-1}, 17,654$ collected reflections $\left(3.516^{\circ} \leq \theta \leq 68.228^{\circ}, \quad-9 \leq h \leq 12, \quad-9 \leq k\right.$ $\leq 12,-30 \leq l \leq 30), 4681$ independent reflections $\left(R_{\text {int }}=0.0340\right)$, goodness of fit on $F^{2}: S=1.138, R_{1}=0.0594$ and $w R_{2}=0.1561$ for all 4681 reflections, $R_{1}=0.0508$ and $w R_{2}=0.1350$ for 4020 observed reflections $[I>2 \sigma(I)]$, refining 308 parameters and 6 restraints, semi-empirical absorption corrections from multi-scans $\left(T_{\min }=\right.$ $\left.0.77, T_{\max }=0.92\right)$, and a final electron density between -0.186 and 0.258 e. $\AA^{-3}$.

\subsection{Virus-cell-based antiviral assay}

Throughout the experiments, Vero (African green monkey kidney) cells and chikungunya virus strain 899 were used (Bourjot et al., 2012). Serial dilutions of extract, fractions or pure compounds, as well as the reference compound chloroquine (positive control), were prepared in an assay medium [MEM] Rega3 (Cat. $\mathrm{N}^{\circ} 19993013$; Invitrogen), $2 \%$ FCS (Integro), $5 \mathrm{~mL}$ of $200 \mathrm{mM}$ L-glutamine, and $5 \mathrm{~mL}$ of $7.5 \%$ sodium bicarbonate that was added to empty wells of a 96-well microtiter plate (Falcon, BD) on a liquid handling platform (Freedom EVO200, Tecan). Subsequently, $50 \mu \mathrm{L}$ of a $4 \times$ virus dilution in assay medium were added, followed by $50 \mu \mathrm{L}$ of a cell suspension. This suspension, with a cell density of 25,000 cells $/ 50 \mu \mathrm{L}$, was prepared from a Vero cell line that was sub-cultured in a cell growth medium (MEM Rega3 supplemented with $10 \%$ FCS, $5 \mathrm{~mL}$ of L-glutamine and $5 \mathrm{~mL}$ of sodium bicarbonate) at a ratio of $1: 4$ and grown for seven days in $150 \mathrm{~cm}^{2}$ tissue culture flasks (Techno Plastic Products). The assay plates were returned to the incubator for six to seven days $\left(37^{\circ} \mathrm{C}, 5 \% \mathrm{CO}_{2}, 95-99 \%\right.$ relative humidity), a length of time in which maximal virus-induced cell death or cytopathic effect (CPE) can be observed in untreated, infected controls. Subsequently, the assay medium was aspirated, replaced with $75 \mu \mathrm{L}$ of a $5 \%$ MTS (Promega) solution in a phenol red-free medium and incubated for $1.5 \mathrm{~h}$. Absorbance was measured at a wavelength of $498 \mathrm{~nm}$ (Safire2, Tecan); optical densities (OD values) reached $0.6-0.8$ for the untreated, uninfected controls. Raw data were converted to a percentage of the controls and the $\mathrm{EC}_{50}$ (50\% effective concentration or concentration, which is calculated to inhibit virus-induced cell death by $50 \%$ ) and $\mathrm{CC}_{50}$ values ( $50 \%$ anti-metabolic concentration or a concentration that is calculated to inhibit the overall cell metabolism by 50\%) were derived from the dose-response curves. All assay conditions producing an antiviral effect exceeding 50\% were checked microscopically for minor signs of CPE or adverse effects on the host cell (i.e., altered cell morphology). A compound is only considered to elicit a selective antiviral effect on virus replication when following microscopic quality control, at least at one concentration of compound, and when no CPE nor any adverse effect is observed (image resembling untreated, uninfected cells). Multiple, independent experiments were performed.

\section{Acknowledgements}

This work was supported by the Centre de Recherche et de Veille des maladies émergentes dans l'Océan Indien (CRVOI), by the Regional Council of La Réunion and by the European Regional Development Fund (ERDF). The authors are very grateful to E. Boyer and D. Strasberg (UMR C_53 PVBMT) for their contribution to plant material identification and species collection, to M.-T. Martin for her help and advice in NMR studies, to A. Marvilliers and B. Illien for their helpul discussions. We would like to acknowledge $C$. Collard, S. Delmotte and T. Bellon for their assistance with the collection of the biological data.

\section{Appendix A. Supplementary data}

Supplementary data associated with this article can be found, in the online version, at http://dx.doi.org/10.1016/j. phytol.2015.04.023.

\section{References}

Adolf, W., Hecker, E., 1980. New irritant diterpene-esters from roots of Stillingia sylvatica L. (Euphorbiaceae). Tetrahedron Lett. 21, 2887-2890.

Allard, P., Martin, M., Tran Huu Dau, M., Leyssen, P., Gueritte, F., Litaudon, M., 2012a. Trigocherrin A: the first natural chlorinated daphnane diterpene orthoester from Trigonostemon cherrieri. Org. Lett. 14, 342-345.

Allard, P.M., Leyssen, P., Martin, M.T., Bourjot, M., Dumontet, V., Eydoux, C. Guillemot, J.C., Canard, B., Poullain, C., Gueritte, F., Litaudon, M., 2012b. Antiviral chlorinated daphnane diterpenoid orthoesters from the bark and wood of Trigonostemon cherrieri. Phytochemistry 84, 160-168.

Bourjot, M., Delang, L., Nguyen, V.H., Neyts, J., Gueritte, F., Leyssen, P., Litaudon, M., 2012. Prostratin and 12-O-tetradecanoylphorbol 13-acetate are potent and selective inhibitors of chikungunya virus replication. J. Nat. Prod. 75, 2183-2187.

Bourjot, M., Leyssen, P., Neyts, J., Dumontet, V., Litaudon, M., 2014. Trigocherrierin A. a potent inhibitor of chikungunya virus replication. Molecules 19, 3617-3627.

Busch, T., Schuster, H., Kirschning, A., 2008. Determination of the absolute configuration of the diterpene tonantzitlolone B. Tetrahedron Lett. 49, 5273-5275.

Chapuis, J., Sordat, B., Hostettmann, K., 1988. Screening for cytotoxic activity of plants used in traditional medecine. J. Ethnopharmacol. 23, 273-284. 
Corlay, N., Delang, L., Girard-Valenciennes, E., Neyts, J., Clerc, P., Smadja, J., Gueritte, F., Leyssen, P., Litaudon, M., 2014. Tigliane diterpenes from Croton mauritianus as inhibitors of chikungunya virus replication. Fitoterapia 97, 87-91.

Cota, B.B., Johann, S., Oliveira, D.M., Siqueira, E.P., Souza-Fagundes, E.M., Cisalpino, P. S., Alves, T.M.A., Zani, C.L., 2011. Biological potential of Stillingia oppositifolia. Rev. Bras. Farmacogn. 21, 70-77.

Dräger, G., Jeske, F., Kunst, E., Lopez, E.G., Sanchez, H.V., Tsichritzis, F., Kirschning, A. Jakupovic, J., 2007. Tonantzitlolone and other diterpenes from Stillingia sanguinolenta. Eur. J. Org. Chem. 30, 5020-5026.

Flack, H.D., 1983. On enantiomorph-polarity estimation. Acta Crystallogr. A 39, 876-881.

Flack, H.D., Shmueli, U., 2007. The mean-square Friedel intensity difference in P1 with a centrosymmetric substructure. Acta Crystallogr. A 63, 257-265.

Hérin, M., Colin, M., Tursch, B., 1976. Chemical studies of marine invertebrates. XXV1. Flexibilene, an unprecedented fifteen-membered ring diterpene hydrocarbon from the soft coral Sinularia flexibilis (Coelenterata, Octocorallia Alcyonacea). Bull. Soc. Chim. Belg. 85, 801-803.

Hooft, R.W., Straver, L.H., Spek, A.L., 2008. Determination of absolute structure using Bayesian statistics on Bijvoet differences. J. Appl. Crystallogr. 41, 96-103.

Kaur, P., Chu, J.J., 2013. Chikungunya virus: an update on antiviral development and challenges. Drug Discov. Today 18, 969-983.

Kazlauskas, R., Murphy, P.T., Wells, R.J., Schönholzer, P., Coll, J.C., 1978. Cembranoid constituents from an australian collection of the soft coral Sinularia flexibilis. Aust. J. Chem. 31, 1817-1824.

Leyssen, P., Smadja, J., Rasoanaivo, P., Gurib-Fakim, A., Mahomoodally, M., Canard, B. Guillemot, J.C., Litaudon, M., Gueritte, F., 2014. Biodiversity as a source of poten and selective inhibitors of chikungunya virus replication. In: Gurib-Fakim, A. (Ed.), Novel Plant Bioressources: Application in Food, Medicine and Cosmetics. John Wiley \& Sons, pp. 151-161.

Lima, M.A., Lima, J.Q., Arriaga, Â., Andrade-Neto, M., Santiago, G.M., Bezerra, B.P., Fereira, Y.S., Veras, H.N.H., Braz-Filho, R., 2009. Chemical constituents from Sebastiania macrocarpa Muell. Muell. Arg. (Euphorbiaceae). Quim. Nova 32, 348-353.

Luo, X.D., Wu, S.H., Ma, Y.B., Wu, D.G., 2001. ent-Pimarane derivatives from Dysoxylum hainanense. Phytochemistry 57, 131-134.
McMurry, J., Matz, J.R., Kees, K.L., Bock, P.A., 1982. Synthesis of flexibilene: a naturally occurrring 15-membered-ring diterpene. Tetrahedron Lett. 23 , 1777-1780.

Nothias-Scaglia, L.F., Retailleau, P., Paolini, J., Pannecouque, C., Neyts, J., Dumontet, V., Litaudon, M., 2014. Jatrophane diterpenes as inhibitors of chikungunya virus replication: structure-activity relationship and discovery of a potent lead. J. Nat. Prod. 77, 1505-1512.

Parsons, S., Flack, H.D., Wagner, T., 2013. Use of intensity quotients and differences in absolute structure refinement. Acta Crystallogr. B 69, 249-259.

Pflugrath, J.W., 1999. The finer things in X-ray diffraction data collection. Acta Crystallogr. D 55, 1718-1725.

Picot, M., Subratty, A., Mahomoodally, M., 2014. Phytochemical profile and antioxidant properties of six medicinal plants traditionally used in the management of diabetes in Mauritius. Pharmacologia 5, 42-49.

Rayanil, K.O., Limpanawisut, S., Tuntiwachwuttikul, P., 2013. Ent-pimarane and enttrachylobane diterpenoids from Mitrephora alba and their cytotoxicity against three human cancer cell lines. Phytochemistry 89, 125-130.

Renault, P., Solet, J.L., Sissoko, D., Balleydier, E., Larrieu, S., Filleul, L., Lassalle, C., Thiria, J., Rachou, E., de Valk, H., Ilef, D., Ledrans, M., Quatresous, I., Quenel, P., Pierre, V., 2007. A major epidemic of chikungunya virus infection on Reunion Island, France, 2005-2006. Am. J. Trop. Med. Hyg. 77, 727-731.

Sequeiros, C., López, L.M.I., Caffini, N.O., Natalucci, C.L., 2003. Proteolytic activity in some Patagonian plants from Argentina. Fitoterapia 74, 570-577.

Sheldrick, G.M., 2008. A short history of SHELX. Acta Crystallogr. A 64, 112-122.

Spek, A.L., 2009. Structure validation in chemical crystallography. Acta Crystallogr. D $65,148-155$.

Thiberville, S.D., Moyen, N., Dupuis-Maguiraga, L., Nougairede, A., Gould, E.A., Roques, P., de Lamballerie, X., 2013. Chikungunya fever: epidemiology clinical syndrome, pathogenesis and therapy. Antiviral Res. 99, 345-370.

Wittenberg, R., Beier, C., Dräger, G., Jas, G., Jasper, C., Monenschein, H., Kirschning, A., 2004. Towards the total synthesis of tonantzitlolone--preparation of key fragments and the complete carbon backbone. Tetrahedron Lett. 45, 4457-4460. 